\title{
Feichtinger, Johannes and Gary B. Cohen, eds. 2014. Understanding Multiculturalism: The Habsburg Central European Experience. New York, NY: Berghahn Books. 246 pp.
}

\author{
Reviewed by Christopher M. VanDemark", New York University
}

In Nations and Nationalism Since 1780: Programme, Myth, Reality, Eric Hobsbawm suggests that nationalism and nationhood, constructed essentially from above, cannot be "... understood unless also analyzed from below, that is in terms of the assumptions, hopes, needs, longings and interests of ordinary people, which are not necessarily national and still less nationalist" (Cambridge, UK: Cambridge UP, 1991, 10). Borrowing from this leftist interpretation of nationalist development, the collection of articles featured in Understanding Multiculturalism: The Habsburg Central European Experience examines the social, political, and cultural realities of heterogenous societies through the prism of Habsburg Central Europe. The contributors to this volume reject nation-based approaches to multiculturalism, identity, and difference, turning toward a revised conceptualization of national development that has gained traction in recent years. Underscoring the historically contingent, fluid character of group cultures and ethnic loyalties, Understanding Multiculturalism develops a transdisciplinary framework that conceives of cultural diversity as a "... meshwork of similarities and differences that describes ongoing processes both of negotiation, transfer, and translation and of marking the boundaries of which everyday life consists" (10). In delineating the shifting, unstable demarcations of multicultural coexistence, the articles included in Feichtinger and Cohen's volume are firmly ensconced in a historiographic tradition cultivated by Tara Zahra, Robert Nemes, Pieter Judson, Jeremy King, and others, whose influential works underscore the constructed, contested nature of nationalist development in modern Central Europe. Building on this analytic approach, the volume's contributors aim to "... analyze and understand the different manifestations of multiculturalism as a political strategy or discourse with which new boundaries of inclusion or exclusion were drawn, and as a mode of understanding and practice used by social actors for coping with diversity" (9). This optic enables the authors to reconceptualize the cultural heterogeneity of Habsburg Central Europe as a "... plurality of coexisting and intersecting, overlapping and antagonistic spaces of communication," a pluricultural "laboratory" in which processes of global relevance emerged (204).

The edited collection of articles is theoretically sophisticated and illuminating, transgressing traditional disciplinary boundaries with incisive, well-developed arguments that challenge stale notions of multiculturalism, hybridity, and nationalist mobilization. The volume's

*mv352@nyu.edu

(cc) $\mathrm{Br}$

ULLS D-Serle
New articles in this journal are licensed under a Creative Commons Attribution 4.0 International License.

This journal is published by the University Library System of the University of Pittsburgh as part of its D-Scribe Digital Publishing Program and is cosponsored by the University of Pittsburgh Press 
VanDemark, Christopher M. "Feichtinger, Johannes and Gary B. Cohen, eds. 2014. Understanding

Multiculturalism: The Habsburg Central European Experience. New York, NY: Berghahn Books. 246 pp."

Hungarian Cultural Studies. e-Journal of the American Hungarian Educators Association, Volume 11 (2018) DOI:

10.5195/ahea.2018.345

first section delineates several approaches to "... understanding processes of identity formation in culturally diverse societies" through a trans-geographic lens (10). In his chapter on pluricultural and polyglot spaces, Anil Bhatti suggests that postcolonial discourses offer a more comprehensive interpretive framework for understanding the particularities of the pluricultural experience in Habsburg Central Europe than methodological conceptualizations of heterogeneity that compartmentalize, demarcate, and isolate. Escaping nationally encoded concepts of multiculturalism, Bhatti's integrative approach unearths the structural parallels between India and Europe, contending that the polyglossia of the East offers historians of Central Europe a unique, implicitly comparative lens through which to examine cultural diversity in the (former) Habsburg lands. In his chapter on hybrid culture in Latin America, Michael Rössner likewise develops a theoretical model that incorporates the rhetorical patterns of postcolonial thought, this time addressing the incongruities of European identity through mestizaje discourses and debates. Pieter Judson's chapter on identity formation and language politics in the Austrian hinterlands rounds out the first portion of the volume, exploring the tensions between nationalizing ideologies on the one hand and the experiences of ordinary Austrians on the other. Consistent with Jeremy King's interpretation of plurilingualism in Habsburg Budweis, Judson contends that language difference did not necessarily inculcate feelings of national belonging; instead, other forms of self-identification structured more emphatically the everyday lifeworlds of rural Austrians living on the language frontier.

The articles in the middle section of the book "... raise questions about the dynamics of multicultural societies and the relationship to politics and the state" (11). Pushing eastward, Patrice M. Dabrowski explores the paradoxes of interwar state-building in newly reconstituted Poland. Considering the geographically peripheral, multiethnic Hutsul Region, Dabrowski contends that the "nationalizing" state eagerly fostered multiculturalism in these borderland communities, exploiting bureaucratic channels to stoke the nativeness of the regionally conscious highlanders. In "Multiculturalism Against the State: Lessons from Istria," Pamela Ballinger analyzes the particularities of regionalism in the Istrian lands, interrogating the ways in which local figures cultivated a curated marginality that was articulated against the Croatian state. Borrowing from Habsburgian and Yugoslav conceptualizations of political multiculturalism, Istrianness was defined linguistically, structuring the ways in which cultural plurality and ethnic diversity were practiced at the local level. Writing on migration in the modern Austrian state, Michael John examines “... the patterns of migration to the Republic of Austria since World War I, some of the social consequences, and the political debates that have arisen about migration and to what extent Austrian society should be considered multicultural..." (122). In his intriguing and topical article, John charts the spasmodic trajectory of Austrian migration and the politics of inclusion, assimilation, and integration that continue to influence conceptions of multiculturalism in present-day Central Europe.

The final section of the volume considers the multivalent ways in which ordinary Habsburg subjects expressed and negotiated identities in multicultural settings. Using multilingual diaries and recipe books, Oto Luthar demonstrates the persistence of transnational self-identification in peripheral regions of the Habsburg Monarchy. Setting his micro-historical analysis in the Slovenian region of Prekmurje, Luthar argues that multilingualism was a salient feature of these borderland communities, structuring practices of everyday communication and intercultural cohabitation despite the nationalizing scheme of local activist groups. Andrei 
Corbea-Hoisie covers a similar terrain in his contribution, "On 'Neighbors' and 'Strangers,", using multiculturalism as a framework for examining identity formation in Habsburg Bukovina. Borrowing from Norbert Elias, Corbea-Hoisie suggests that the accelerated pace of modernity changed the social landscape of small, hinterland communities as in-migrants increasingly gained and maintained enviable positions in professional life. Ultimately, this Bukovinian model "... stood for suppression, a life in conflict and hostile coexistence, missing any intercultural encounter," as an influx of new, "strange" inhabitants fueled intergroup hostilities and political confrontation in intransigent, peripheral spaces (13). In the volume's concluding chapter, Moritz Csáky problematizes teleological narratives of national development, deconstructing categories that otherwise continue to inform historiography and cultural memory. Instead of these, he proposes an interpretive model that reappraises pluriculturalism as an ordinary state of life, in which culture is reconceptualized as a "... repertoire of scripts of behavior, best described from the perspective of communication" (195). From this analytic vantage point, the Habsburg case may be considered a "laboratory" of transcultural interaction and exchange.

Freed from the arbitrary reductions of traditional nationalist discourses, the articles featured in Understanding Multiculturalism accentuate the contingent nature of identity formation and perceptions of selfhood in pluricultural milieus. The volume reflects a growing awareness in socio-historical circles of the multidimensional complexities of modern statebuilding and the descriptive paucity of state-centrism, thus developing an approach that embraces the mutable qualities of multicultural locality. Proposing an interpretive scheme that foregrounds the mutually constitutive relationship among nationalizing forces, administrative institutions, and local societies, the book offers a more nuanced portrait of the development of national loyalties that hones in on the ambiguities of behavior and perception in the borderland regions of Habsburg Central Europe. Methodologically, the volume's contributors express some interest in spatiality, anchoring their analyses in the unstable linkages that connected everyday practices on the ground with nationalizing scheme from above. Through this lens, the constraints of ethnic and national categories become clearer and more discernable. Moreover, the volume provides a useful analytic springboard for thinking about conceptualizations of multiculturalism and diversity in late-imperial Transleithania. As Robert Nemes, Mary Gluck, and others have shown, nationalization in nineteenth-century Budapest was an uneven, dynamic process, with nationalist associations influencing consumer habits through boycotts and mobilizing social groups via print media, clubs, and community organizations. This exclusionary nationalism ostracized ethnic and religious minorities by formulating institutions that supported and replicated a narrow vision of "authentic" Hungarian-ness. A fascinating contribution to the growing body of literature on diversity, spatiality, and nationalizing practices, Understanding Multiculturalism will be a welcomed addition to the shelves of modern historians of any field or focus. 